\title{
Association of HLA-DRB1 Alleles and Autoimmune Hepatitis in Turkish Patients
}

\author{
Otoimmün Hepatit ile HLA-DRB1 Alel İlişkisi
}

\author{
Çiğdem KEKIK, Yalçın SEYHUN, Gonca Emel KARAHAN, Binnur PINARBAȘI, ${ }^{1}$ \\ Kadir DEMIR, ${ }^{1}$ Sabahattin KAYMAKOĞLU, ${ }^{1}$ Mahmut ÇARIN \\ Departments of Medical Biology and ${ }^{1}$ Gastroenterohepatology, İstanbul Medical Faculty of İstanbul University, İstanbul
}

Submitted / Başvuru tarihi: 30.01.2009 Accepted / Kabul tarihi: 16.03.2009

Objectives: Autoimmune hepatitis $(\mathrm{AlH})$ which is characterized by hypergammaglobulinemia and a wide range of circulating auto antibodies is a necroinflammatory liver disease of unknown aetiology. Immunogenetic studies have shown the association of autoimmunity with HLA (Human Leukocyte Antigen) alleles. Furthermore, they have shown a decrease in the expression of HLA antigens on lymphocyte surface and a dysregulation of gene expression arranged by HLA. A significant association is found between $\mathrm{AlH}$ and HLA-DRB1 ${ }^{*} 03$, ${ }^{*} 04$ and ${ }^{*} 13$ alleles in various studies. We performed HLA-DRB1 genotyping in Turkish patients with $\mathrm{AlH}$.

Patients and Methods: The study group consisted of 113 patients (55 females, 58 males; mean age 44.8 \pm 21.21 ; range 10-82) with $\mathrm{AlH}$ and 300 healthy individuals (198 females, 102 males; mean age $32.4 \pm 10.48$; range 17-50). After DNA isolation by standard methods, HLA-DRB1 typing was performed by using polymerase chain reaction amplification with sequence-specific primers (PCR-SSP).

Results: HLA-DRB ${ }^{*} 03$ allele had a significantly increased frequency in the patient group. On the other hand, DRB1*13 allele had a significantly decreased frequency compared with the healthy controls.

Conclusion: HLA-DRB ${ }^{*} 03$ might play a role in the pathogenesis of AlH while HLA-DRB1*13 might have a protective role for AlH.

Key words: HLA-DRB; autoimmunity; autoimmune hepatitis.
Amaç: Otoimmun hepatit $(\mathrm{OIH})$, dolaşımdaki otoantikorlar ve yüksek serum globulin düzeyiyle birlikte seyreden, nedeni bilinmeyen kronik bir nekroinflamatuar karaciğer hastalığıdır. İmmünogenetik çalışmalarda, otoimmunite ile HLA (Human Leukocyte Antigen) antijenleri arasında ilişki bulunmuş olup, lenfositlerin yüzeyinde bulunan HLA antijeninde azalma ve HLA tarafından düzenlenen genlerin ekspresyonunda bozulma saptanmıştır. Yapılan çalışmalarda otoimmun hepatit ile HLA-DRB1*03, ${ }^{*} 04,{ }^{*} 13$ antijenleri arasında anlamlı birliktelikler bulunmuştur. $\mathrm{Bu}$ çalışmada otoimmun hepatit ile HLA-DRB1 antijenleri arasındaki ilişki araştırılmıştır.

Hastalar ve Yöntemler: Çalışmamıza 113 hasta (55 kadın, 58 erkek; ort. yaş 44.8 \pm 21.21 ; dağılım 10-82) ve otoimmun hastalığı olmayan 300 sağlıklı birey (198 kadın, 102 erkek; ort. yaş $32.4 \pm 10.48$; dağııım 17-50) dahil edilmiştir. Standart yöntemler ile DNA izolasyonu yapıldıktan sonra PCR-SSP yöntemi ile HLA-DRB1 doku tiplendirmesi yapılmıştır. Elde edilen sonuçlar Fisher's exact testi kullanılarak değerlendirilmiştir.

Bulgular: Hasta grubunda DRB1*03 alel sıkığının kontrol grubuna oranla yüksek bulunurken DRB1*13 aleli ise kontrole göre anlamı olarak düşük sıklıkta olduğu görülmüştür.

Sonuç: HLA-DRB1*03 alelinin hastalığa yatkınlığı HLA-DRB ${ }^{*} 13$ alelinin ise hastalığa karşı koruyucu özellikte olduğu düşünülmektedir.

Anahtar sözcükler: HLA-DRB1; otoimmünite; otoimmün hepatit.

Correspondence (iletişim adresi): Dr. Çiğdem Kekik. İstanbul Üniversitesi İstanbul Tıp Fakültesi Tıbbi Biyoloji Anabilim Dalı, 34093 Istanbul. Tel: 0212 - 6351168 Fax (Faks): 0212 - 6351168 e-mail (e-posta): citcim@gmail.com

(c) Trakya Üniversitesi Tıp Fakültesi Dergisi. Ekin Tıbbi Yayıncııı tarafından basılımışır. Her hakkı sakııır.

c) Medical Journal of Trakya University. Published by Ekin Medical Publishing. All rights reserved. 
The concept of autoimmunity was first predicted by Nobel Laureate Paul Ehrlich at the start of the twentieth century, and he described it as 'horror autotoxicus'. His experiments led him to conclude that the immune system is normally focused on responding to foreign materials and has an inbuilt tendency to avoid attacking self tissues. But when this process goes wrong, the immune system can attack self tissues resulting in autoimmune disease. ${ }^{[1]}$ All individuals are tolerant of their own potentially antigenic substances, and failure of self tolerance is the fundamental cause of autoimmunity. ${ }^{[2]}$

Our knowledge about autoimmunity has progressed especially with development of animal models special to these diseases and definition of genes which lead to predisposition within last two decades. However, the aetiology of most of the autoimmune diseases remains to be unknown. Animal models and studies have shown that viruses might play an important role in aetio-pathogenesis of autoimmune disease affecting 3-5\% of the population. Autoimmune hepatitis which is characterized by hypergammaglobulinemia and a wide range of circulating auto-antibodies is a necro-inflammatory liver disease of unknown aetiology. ${ }^{[3]}$

Genetic studies have shown that individuals who express specific HLA alleles are susceptible to autoimmune diseases. ${ }^{[4-7]}$ Moreover, autoimmune hepatitis and HLA-DRB1*03, *04 and *13 alleles were found to be in significant association in various studies. ${ }^{[8-10]}$ We aimed at determining the association of HLA-DRB1 alleles with AIH in Turkish patients.

\section{PATIENTS AND METHODS}

The study group consisted of 113 patients (55 females, 58 males; mean age $44.8 \pm 21.21$; range $10-82$ ) with $\mathrm{AIH}$, diagnosed at the Department of Gastroenterohepatology, İstanbul Medical Faculty, Division of Internal Medicine between 1999-2006 and 300 healthy individuals (198 females, 102 males; mean age 32.4 \pm 10.48 ; range 17-50) who were bone marrow volunteers. None of the individuals in the control group were relatives with each

Table 1. Frequency distribution of HLA-DRB1 alleles

\begin{tabular}{lcc}
\hline & Patients $(\mathrm{n}=113)$ & Controls $(\mathrm{n}=300)$ \\
\hline DRB1*01 & $13(5.75 \%)$ & $41(6.83 \%)$ \\
DRB1*03 & $37(16.37 \%)$ & $59(9.83 \%)$ \\
DRB1*04 & $34(15.04 \%)$ & $83(13.83 \%)$ \\
DRB1*07 & $16(7.07 \%)$ & $44(7.33 \%)$ \\
DRB1*08 & $1(0.44 \%)$ & $18(3 \%)$ \\
DRB1*09 & $1(0.44 \%)$ & $5(0.83 \%)$ \\
DRB1*10 & $7(3.09 \%)$ & $16(2.66 \%)$ \\
DRB1*11 & $49(21.68 \%)$ & $124(20.66 \%)$ \\
DRB1*12 & $2(0.88 \%)$ & $11(1.83 \%)$ \\
DRB1 13 & $13(5.75 \%)$ & $68(11.33 \%)$ \\
DRB1*14 & $16(7.07 \%)$ & $31(5.16 \%)$ \\
DRB1*15 & $21(9.29 \%)$ & $52(8.66 \%)$ \\
DRB1*16 & $16(7.07 \%)$ & $48(8 \%)$ \\
\hline
\end{tabular}

Table 2. Significant HLA-DRB1 alleles

\begin{tabular}{lccl}
\hline & Patients $(\mathrm{n}=113)$ & Controls $(\mathrm{n}=300)$ & $p$ \\
\hline $\mathrm{DRB1}^{*} 03$ & 37 & 59 & 0.01 \\
$\mathrm{DRB1}^{*} 08$ & 1 & 18 & 0.03 \\
DRB1 $^{*} 13$ & 13 & 68 & 0.017 \\
\hline
\end{tabular}

other or patients. All patients satisfied the established criteria for the diagnosis of AIH. Deoxyribonucleic acid (DNA) was extracted from peripheral blood leukocytes by salt precipitation method. HLA-DRB1 typing was performed by using polymerase chain reaction amplification with sequence-specific primers (PCR-SSP) (Olerup SSP AB, Hasselstigen 1, SE-133 33 Saltsjöbaden, Sweden). Chi-square and Fisher's exact test were used for statistical analysis (SPSS 12.0 for Windows). $\mathrm{p}$ values $<0.05$ were considered as significant.

\section{RESULTS}

Allelic frequencies of HLA-DRB1 are shown in Table 1. HLA-DRB ${ }^{*} 03$ allele had a significantly increased frequency in the patient group. On the other hand, DRB1*13 and DRB ${ }^{*} 08$ alleles had a significantly decreased frequency in the patients when compared with the healthy group (Table 2). An association between other alleles and autoimmune hepatitis could not be determined. Furthermore, frequency of HLA-DRB1 alleles did not differ in males and females (Table 3 ). No significant differences could be established for HLA-DRB3, DRB4 and DRB5 alleles between patients and healthy controls.

\section{DISCUSSION}

Autoimmune hepatitis (AIH) is a disease of unknown aetiology but is presumed to have a basis in aberrant auto reactivity. ${ }^{[1]}$ Autoimmune hepatitis is characterized with hypergammaglobulinemia, a wide range of circulating auto-antibodies and periportal hepatitis in liver biopsy. Immunosuppressive treatment including corticosteroids plus azathioprine or 6-mercaptopurine, remission induction and maintenance are standard

Table 3. Distribution of HLA-DRB1 alleles according to gender

\begin{tabular}{|c|c|c|}
\hline & Patients $(n=113)$ & Controls $(n=300)$ \\
\hline DRB1*01 & 4 & 9 \\
\hline DRB $1 * 03$ & 19 & 18 \\
\hline DRB1*04 & 18 & 16 \\
\hline DRB1*07 & 10 & 6 \\
\hline $\mathrm{DRB} 1 * 08$ & 0 & 1 \\
\hline DRB1*09 & 0 & 1 \\
\hline DRB1*10 & 2 & 5 \\
\hline DRB1*11 & 24 & 25 \\
\hline DRB1*12 & 2 & 0 \\
\hline DRB1*13 & 9 & 4 \\
\hline DRB1*14 & 6 & 10 \\
\hline DRB1*15 & 10 & 11 \\
\hline DRB1*16 & 6 & 10 \\
\hline
\end{tabular}


treatment protocols. Furthermore liver transplantation has been an extremely successful treatment option for patients with decompensate liver cirrhosis. ${ }^{[12,13]}$

Autoimmunity defines the development of immune response to auto-antigens and remains to be an important cause of many diseases. Some genes contribute to the development of autoimmune diseases and family studies have exhibited that autoimmune diseases show associations with some genetic regions suggesting Major Histocompatibility Complex (MHC) genes to be the most important. Thus, many autoimmune diseases were determined to associate with HLA alleles in MHC gene region. It is clearly known that the basic function of HLA molecules is to present peptides to T cells. Auto antigens are processed by professional antigen-presenting cells (APC) and by binding to the groove of particularly HLA-DRB1 molecules they are presented to CD4+T helper cells. ${ }^{[14]}$ This data also emphasizes the significant role of $\mathrm{T}$ cells in this kind of diseases. The frequency of certain HLA alleles is found to be higher in patients in some diseases (rheumatoid arthritis, Graves's disease) than the controls. ${ }^{[15-18]}$ However, although carrying a certain HLA allele might increase the risk of developing an autoimmune disease, the allele itself cannot be accepted as a cause of the disease.

In addition to the environmental factors, genetic susceptibility plays an important role in the development of autoimmune hepatitis. ${ }^{[19-21]}$ Immune response starts with the recognition of self or non-self antigens presented by HLA molecules. Differences in the immune responses within different individuals are due to the allelic variations of HLA alleles. The association of HLA-DRB1*03 with auto-immune hepatitis has been shown long ago. Furthermore, high-resolution DNA-based techniques have indicated that DRB1*0301 and DRB1*0401 are the alleles associated with the susceptibility to type-1 autoimmune hepatitis in white North Americans. ${ }^{[22,23]}$ HLA DRB1*03 and DRB1*04 are independent risk factors for type- 1 autoimmune hepatitis in white North American and Northern European patients. Patients with DRB $1{ }^{*} 03$ are younger at disease onset than patients with HLA DRB1*04, and they respond less well to corticosteroid therapy. Patients with HLA DRB1*04 are more commonly women, have a higher frequency of concurrent immune diseases, and respond better to corticosteroid treatment. Patients with HLA DRB1*03 and DRB1*04 who had three or four alleles encoding lysine at position $\mathrm{DRb} 7$ within the class II MHC molecule developed cirrhosis more commonly (75\% vs $9 \%, \mathrm{p}=0.05)$. In addition, a protective effect for HLA-DRB1*13 has been shown in several studies with $\mathrm{AIH} \cdot{ }^{[18,24,25]}$ A study with type 1 diabetes reported low frequency for DRB1*04 and DRB1*08 whereas in other studies with rheumatoid arthritis and systemic lupus erythematosus, the frequency for DRB1*08 was significantly high. ${ }^{\text {[26-29] }}$
In the present study in concordance with the previous studies, the frequency of HLA-DRB1*03 was significantly high in the patient group suggesting that this allele might be associated with disease susceptibility. On the other hand, the high frequency of HLA-DRB1*13 and DRB $1{ }^{*} 08$ alleles in the control group and the lower frequency in the patient group indicates a protective role for this allele also in Turkish population.

\section{REFERENCES}

1. Bell E, Bird L. Autoimmunity. Nature 2005;435:583.

2. Rioux JD, Abbas AK. Paths to understanding the genetic basis of autoimmune disease. Nature 2005;435:584-9.

3. Krawitt EL. Autoimmune hepatitis. N Engl J Med 1996;334:897-903.

4. Svejgaard A, Platz P, Ryder LP. HLA and disease susceptibility: clinical implications. Clin Immunol Allergy 1984;4:567-80.

5. Svejgaard A, Buus S, Fugger L, editors. HLA and disease: the molecular basis. New Jersey: John Wiley and Sons; 1997. p. 301-13.

6. Flavell RA, Hafler DA. Autoimmunity. What is the turning point? Curr Opin Immunol 1999;11:635-7.

7. Thorsby E. Invited anniversary review: HLA associated diseases. Hum Immunol 1997;53:1-11.

8. Czaja AJ, Carpenter HA, Moore SB. HLA DRB1*13 as a risk factor for type 1 autoimmune hepatitis in North American patients. Dig Dis Sci 2008;53:522-8.

9. Montano-Loza AJ, Carpenter HA, Czaja AJ. Clinical significance of HLA DRB103-DRB104 in type 1 autoimmune hepatitis. Liver Int 2006;26:1201-8.

10. Qiu DK, Ma X. Relationship between human leukocyte antigen-DRB1 and autoimmune hepatitis type I in Chinese patients. J Gastroenterol Hepatol 2003;18:63-7.

11. McFarlane IG. The relationship between autoimmune markers and different clinical syndromes in autoimmune hepatitis. Gut 1998;42:599-602.

12. Johnson PJ. Treatment of autoimmune hepatitis. Gut 1997;41:3-4.

13. Reich DJ, Fiel I, Guarrera JV, Emre S, Guy SR, Schwartz $\mathrm{ME}$, et al. Liver transplantation for autoimmune hepatitis. Hepatology 2000;32:693-700.

14. Qiu DK, Ma X. Relationship between human leukocyte antigen-DRB1 and autoimmune hepatitis type I in Chinese patients. J Gastroenterol Hepatol 2003;18:63-7.

15. Delgado-Vega AM, Anaya JM. Meta-analysis of HLA-DRB1 polymorphism in Latin American patients with rheumatoid arthritis. Autoimmun Rev 2007;6:402-8.

16. Lin L, Chen Y, Xiao Z, Huang S, Yang Z. The association of HLA-DRB1 alleles with rheumatoid arthritis in the Chinese Shantou population: a follow-up study. Biochem Cell Biol 2007;85:227-38.

17. Sasaki M, Yuzawa M, Saito T, Ikoma A, Tamemoto $H$, Kawakami M, et al. New HLA DRB1 and DQB1 haplotypes in a pedigree of familial Graves' disease in Japan. Endocr J 2007;54:721-5.

18. Yarman S, Oguz F, Carin M. HLA-DRB1*03 is a susceptibility gene in patients with Graves' disease with and without ophthalmopathy. Int J Immunogenet 2007;34:23-5.

19. McFarlane IG. Pathogenesis of autoimmune hepatitis. Biomed Pharmacother 1999;53:255-63.

20. Pando M, Larriba J, Fernandez GC, Fainboim H, Ciocca M, Ramonet M, et al. Pediatric and adult forms of type I auto- 
immune hepatitis in Argentina: evidence for differential genetic predisposition. Hepatology 1999;30:1374-80.

21. Seki T, Ota M, Furuta S, Fukushima H, Kondo T, Hino $\mathrm{K}$, et al. HLA class II molecules and autoimmune hepatitis susceptibility in Japanese patients. Gastroenterology 1992;103:1041-7.

22. Goldberg AC, Bittencourt PL, Mougin B, Cançado EL, Porta G, Carrilho F, et al. Analysis of HLA haplotypes in autoimmune hepatitis type 1: identifying the major susceptibility locus. Hum Immunol 2001;62:165-9.

23. Mackay IR, Davies JM, Rowley MJ. Towards the pathogenesis of autoimmune liver disease. J Autoimmun 1999;13:1639.

24. Donaldson PT, Baragiotta A, Heneghan MA, Floreani A, Venturi C, Underhill JA, et al. HLA class II alleles, genotypes, haplotypes, and amino acids in primary biliary cirrhosis: a large-scale study. Hepatology 2006;44:667-74.

25. Laadhar L, Gassara A, Mahfoudh N, Ben Hadj hmida Y, Kamoun T, Ben Ayed M, et al. Susceptibility markers in
Tunisian first-degree relatives of patients with type 1 diabetes. Ann Endocrinol 2007;68:181-5. [Abstract]

26. Rodríguez-Ventura AL, Yamamoto-Furusho JK, Coyote N, Dorantes LM, Ruiz-Morales JA, Vargas-Alarcón G, et al. HLA-DRB1*08 allele may help to distinguish between type 1 diabetes mellitus and type 2 diabetes mellitus in Mexican children. Pediatr Diabetes 2007;8:5-10.

27. Gombos Z, Wachowicz J, Veijola R, Akerblom HK, Simell $\mathrm{O}$, Knip M, et al. Human leukocyte antigen non-class II determinants for type 1 diabetes in the Finnish population. Hum Immunol 2006;67:714-21.

28. Al-Swailem R, Al-Rayes H, Sobki S, Arfin M, Tariq M. HLADRB1 association in Saudi rheumatoid arthritis patients. Rheumatol Int 2006;26:1019-24.

29. Calvo-Alén J, Reveille JD, Rodríguez-Valverde V, McGwin G Jr, Baethge BA, Friedman AW, et al. Clinical, immunogenetic and outcome features of Hispanic systemic lupus erythematosus patients of different ethnic ancestry. Lupus 2003;12:377-85. 